\title{
Kinetic Models for Drying Techniques-Food Materials
}

\author{
Uwem Ekwere Inyang, Innocent Oseribho Oboh, Benjamin Reuben Etuk \\ Department of Chemical and Petroleum Engineering, University of Uyo, Uyo, Nigeria \\ Email: uweminyang7@yahoo.com,innocentoboh@uniuyo.edu.ng, bretuk2001@yahoo.com
}

How to cite this paper: Inyang, U.E. Oboh, I.O. and Etuk, B.R. (2018) Kinetic Models for Drying Techniques-Food Materials. Advances in Chemical Engineering and Science, 8, 27-48.

https://doi.org/10.4236/aces.2018.82003

Received: January 18, 2018

Accepted: March 6, 2018

Published: March 9, 2018

Copyright $\odot 2018$ by authors and Scientific Research Publishing Inc. This work is licensed under the Creative Commons Attribution International License (CC BY 4.0).

http://creativecommons.org/licenses/by/4.0/

(c) (i) Open Access

\begin{abstract}
Drying operations can help in reducing the moisture content of food materials for avoidance of microbial growth and deterioration, for shelf life elongation, to minimize packaging and improving storage for easy transportation. Thin-layer drying of materials is necessary to understand the fundamental transport mechanism and a prerequisite to successfully simulate or scale up the whole process for optimization or control of the operating conditions. Researchers have shown that to rely solely on experimental drying practices without mathematical considerations for the drying kinetics, can significantly affect the efficiency of dryers, increase the cost of production, and reduce the quality of the dried product. An effective model is necessary for the process design, optimization, energy integration and control; hence, the use of mathematical models in finding the drying kinetics of agricultural products is very important. The statistical criteria in use for the evaluation of the best model(s) has it that coefficient of determination $\left(R^{2}\right)$ has to be close to unity while the rest statistical measures will have values tending to zero. In this work, the essence of drying using thin-layer, general approaches to modeling for food drying mechanisms thin layer drying models and optimization of the drying processes have been discussed.
\end{abstract}

\section{Keywords}

Drying Kinetics, Thin Layer, Mathematical Modeling, Rate Constant, Diffusion, Statistical Measures

\section{Introduction}

The removal of moisture can be due to simultaneous heat and mass transfer [1]. Purposely it is carried out to reduce water to the level at which microbial spoilage and deterioration reactions are greatly minimized [2]. The dried product 
achieved will minimize transportation, storage, packaging cost and time. Though there are many ways in which drying can be achieved, but the choice of method depend on the material and the sanitary level required [3]. The use of drying of foodstuffs is very common to improve food stability and minimize chemical and physical changes during storage. Hence, drying is the most extensively used technique for food preservation [4]. Moreover, there are various types of drying techniques that can be applied to reduce the water and which attains the purpose of food preservation as has been shown in Singh et al. [4] and Inyang, et al. [5], these include, air drying, hot air drying, sun drying, solar drying, osmotic drying, infra-red drying, oven drying, spray drying, drum drying, microwave drying, freeze drying, vacuum drying, foam mat drying, impingement drying, acoustic drying, explosion puffing drying, hybrid dryers.

Kinetic modeling of process parameters is very useful in food processes. The processes involved are mainly (bio) chemical and physical reactions. These changes proceed at a certain rate and with certain kinetics. Kinetic modeling enables us to describe these changes and their rates quantitatively. In kinetic modeling we have a powerful tool that can help to unravel basic reaction mechanisms. The understanding of the basic mechanisms is vital for quality modeling and quality control [6].

To understand the progress of reactions, knowledge of thermodynamics and kinetics is required. The rate with which a reaction proceeds is the resultant of the driving force and the resistance against change. There is thus an intimate link between thermodynamics and kinetics [6].

Hence, studying drying kinetics will aid in identifying appropriate drying methods and to control the processes of drying. It is also important for engineering and process optimization. It is sometime expensive to conduct a full scale experiment to determine the suitable conditions for drying. Thus, drying kinetics is used to express the moisture removal process and its relation to the process variables and hence, a good understanding of the drying rate is important to develop a drying model [7].

Despite the essence of kinetics, modeling of particulate or thin-layer drying of materials is necessary to understand the fundamental transport mechanism and a prerequisite to successfully simulate or scale up the whole process for optimization or control of the operating conditions. Simple models with a reasonable physical meaning are effective for engineering purposes. Mathematical modeling of dehydration process is an inevitable part of design, development and optimization of a dryer [8]. It mainly involves elaborative study of drying kinetics, which describes the mechanisms and the influence that certain process variables exert on moisture transfer [9]. In other words, it can be used to study the drying variables, evaluate the drying kinetics and to optimize the drying parameters and the conditions [10] [11]. A proper drier design requires knowledge on the characteristics of the material to be dried and the drying kinetics [12]. It is noted that higher temperature implies larger driving force for heat transfer [13] [14]. It 
also accelerates the drying process, as the temperature provides a larger water vapor pressure deficit [15].

\section{Mechanism of Drying}

The main mechanisms of drying are surface diffusion on the pore surfaces, liquid or vapor diffusion due to moisture concentration differences and capillary action in granular and porous foods due to surface forces [16]. Generally, hygroscopic products dry at constant rate and subsequent falling rate periods and drying stops when equilibrium is established. The constant rate period of drying, the physical form of the product and external conditions such as temperature, drying air velocity, direction of air flow and relative humidity have a great influence on the surface of the product being dried in surface diffusion [17] [18]. When the surface film of the solids or particles appears to be dried and the moisture content has been reduced to its critical moisture content then the first falling rate period begins. Unlike the constant rate periods, the falling rate period is controlled by liquid diffusion as a result of moisture concentration differences and the internal conditions of the product. The internal conditions such as moisture content, the temperature and the structure of the product play an important role in the falling rate periods. This phenomena is then replaced by the second falling rate periods of drying namely vapor diffusion due to moisture concentration difference and also internal conditions of the products [19] [20]. It has been accepted that the drying phenomenon of biological products during falling rate period is controlled by the mechanism of liquid and/or vapor diffusion [19] [21]. However, only capillary and liquid diffusion theories are, generally, applicable to the drying of food materials [22]. Diffusion is the dominant physical mechanism governing moisture movement in the material [23] [24] [25], which is dependent on the moisture content of the samples [26]. The moisture contents were expressed on dry basis, which is more convenient for modeling [27] [28].

Figure 1 describes the drying rate and temperature as a function of time. This rate curve can also be used in identifying the dominant mechanism of a product during drying. In the initial drying period, the equilibrium air temperature is usually greater than the temperature of the product [30]. Therefore, the drying rate between $\mathrm{A}$ and $\mathrm{B}$ increases with an increase in temperature of the product until the surface temperature attains equilibrium (Corresponding to line $\mathrm{B}$ to $\mathrm{C}$ ). Under constant conditions, the drying process of agricultural and biological products has been described as a number of steps consisting also of an initial constant rate period (B to $\mathrm{C}$ ) during which drying occurs as if pure water is being evaporated, and one or several falling rate periods where the moisture movement is controlled by combined external-internal resistances or by either external or internal resistance to heat and mass transfer [31]. Mostly, many fruits and vegetables dry during the falling rate periods because the drying process is controlled by a diffusion mechanism. Drying usually stops when steady state equilibrium is reached [16]. During the constant rate period the physical form of 


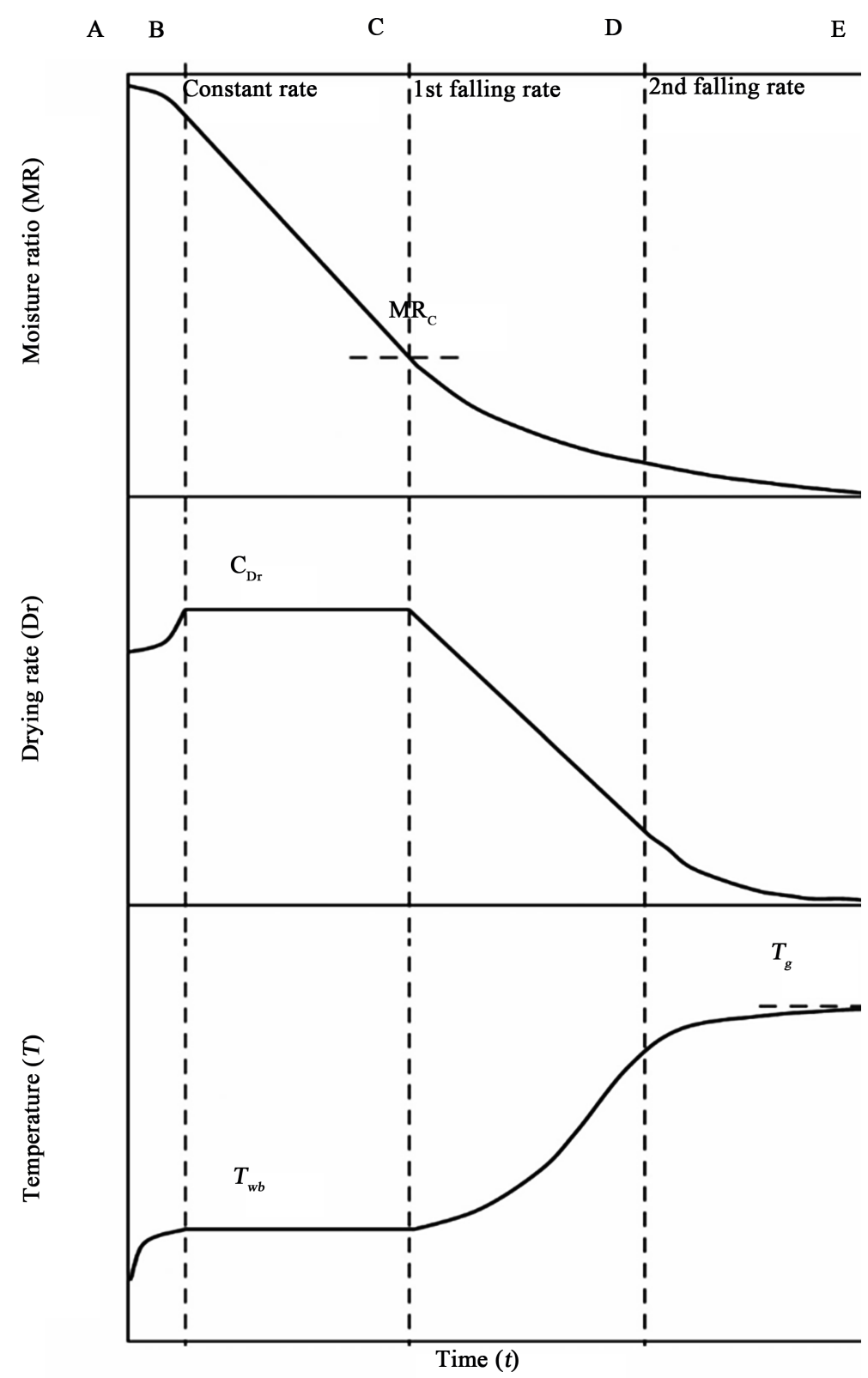

Figure 1. A typical drying curve of agricultural products showing constant rate and falling rate periods [29].

the product is affected, especially the surface of the product. This period is largely controlled by capillary and gravity forces. The conditions of the drying process, like the temperature, drying air velocity, and relative humidity, also affect the product during this stage. The first falling rate period (C to D) begins when the surface film of the product appears to be dry, and the moisture content has decreased to its critical moisture content. As drying continues, the material will then experience a change from the first falling rate period to a phenomenon known as the second falling rate period (D to E) [29].

In literatures, several models like the theoretical, empirical and semi empirical are mentioned for the analysis of the drying of hygroscopic products [21] [32]. 
But the most widely applied categories of thin-layer models are the semi theoretical and empirical models [29] [33] [34] [35].

\section{Thin Layer Drying Process}

Thin layer refers to a layer of sufficiently small product thickness in order that one could consider that air characteristics everywhere in the layer are identically uniform without variance. Thin layer drying process also refers to the drying of individual particles or grains of material which are fully exposed to the drying air .The process is often divided into two periods of drying which are the constant drying rate period and the falling drying rate period [36].

In the constant rate drying period, the material contain so much water that liquid surfaces exist and will dry in a manner comparable to an open faced body of water. The water and its environment, not solid will determine the rate of drying. Wet sand, soil, pigment and washed seeds are examples of materials that initially dry at constant rate. Radiation, conduction or convection provides the energy needed for drying.

In actual practice, drying of agricultural produce takes place in the falling rate period. The falling rate period is bounded by equilibrium moisture content of an equilibrium moisture curve between zero and nearly $100 \%$ relative humidity. Drying in the falling rate period involves two processes namely; the movement of moisture within the material to the surface and removal of moisture from the surface [37]. Furthermore, thin layer drying could be viewed as the drying of one layer of sample particles or slices in abundant supply of drying air with appropriate physical characteristics.

Thin layer drying is also described as the process of removal of moisture from a porous media by evaporation in which excess drying air is passed through a thin layer of a material until the equilibrium moisture content is reached [38] [39].

Thin-layer drying equations fall into three categories namely, theoretical, semi-theoretical, and empirical models.

\subsection{Theoretical Method}

Theoretical models only consider the internal resistance in transfer of moisture while the other two categories are considered to study the external resistance to moisture transfer between air and product [40] [41]. The theoretical models are derived from Fick's second law of diffusion [21]. While semi-theoretical models are generally derived from Fick's second law and its modifications and also, from Newton's law of cooling [16]. Fick's second law of diffusion is the most commonly used theoretical model. Theoretical models are inadequate and tend to generate erroneous results and are complex for practical applications. The theoretical models make too many assumptions leading to a considerable number of errors [40] [42], thus limiting their utilization in the design of dryers [29]. A theoretical equation gives a better understanding of the transport processes 
but an empirical equation gives a better fit to the experimental data without any understanding of the transport processes involved [19].

\subsection{Empirical Method}

The empirical method is a method based on experimental data and dimensionless analysis. The empirical models of drying show a direct relationship between average moisture content and drying time [43]. However, this method omits the fundamentals of the drying process and its parameters have no physical meaning, therefore it does not provide an accurate view of the important processes that occur during the phenomenon while describing the drying curves for certain experimental conditions [44]. Empirical models fails to take into account the fundamentals of drying process and is able to explain only the drying curve for drying condition but not the processes that occurs during drying [45]. Empirical models help to understand the trend of experimental/process variables both dependent and independent. The main challenges faced by the empirical models are that they depend largely on experimental data and provide limited information about the heat and mass transfer during the drying process [16].

\subsection{Semi-Empirical Method}

Semi theoretical models have been developed to ease the use and to fit the drying data of the food material to be dried [46]. Much emphasis has been given to developing semi theoretical models for achieving harmony between theory and ease of use. Such models are generally based on Newton's Law of Cooling applied to mass transfer. When applying this law it is assumed that conditions are isothermal and resistance to moisture transfer is confined only to the surface of the product [47]. Semi theoretical models are the simplified general series solutions of the Fick's second law. These models, however works only when temperature, relative humidity, air velocity and moisture are in the range at which the models are developed. Time requirement is less and shapes of the material dried are not considered in semi theoretical models [48].

Among semi-theoretical models are the model of two terms, the Henderson and Pabis, Lewis, Page and Modified Page [21].

\section{Drying Constant}

In the thin layer drying concept, the drying constant is the combination of drying transport properties such as moisture diffusivity, thermal conductivity, density, specific heat, interface heat, and mass coefficients [49]. Thus, knowledge of transport and material properties is necessary to apply any transport equation [50].

\section{Derivation of Thin layer Models}

Research on the study of the kinetics of thin layer drying is performed with various agricultural products such as seeds, grains, fruits and some plant species 
with economic importance [44]. The Henderson and Pabis model, firstly used for model drying of corn is the first term of general series solution to Fick's law. However, due to inaccuracy and high degree of temperature difference between kernel and air, the model could not be fitted during the first 1 or 2 hour of drying corn [51]. The first two terms of general series solution to Fick's second law is the two term model. The two term model however, does not consider the shape of the product dried. The model assumes constant diffusivity and requires the temperature of the product to be constant [40] [52].

Lewis model is a special case of Henderson and Pabis model. According to Bruce [42] the model is inaccurate; it overestimates the first period and underestimates the last period of drying.

Drying kinetics models does not take into account the effects of interactions by parameters other than the time of drying. Models that incorporate a large number of variables still do not exist but due to the complex non-linear relationship between the kinetics of drying and variables related, the development of such models is not feasible [32] [53]. The concept of thin-layer drying models for characterizing the drying behaviour was suggested, initially, by Lewis [54] who derived the semi-theoretical model for porous hygroscopic materials, which is analogous with Newton's law of cooling. The following model was developed

$$
M R=\frac{X-X_{e}}{X_{o}-X_{e}}=\exp (-k t)
$$

where $M R$ is moisture ratio, $k$ is drying constant $\left(\mathrm{m}^{-1}\right), t$ is drying time, $X$, $X_{e}, X_{o}$ are moisture content at any time, equilibrium and initial, respectively. Page [55] modified the Lewis model by adding a dimensionless empirical constant $(n)$ and used it for study the drying behavior of shelled corns.

$$
M R=\frac{X-X_{e}}{X_{o}-X_{e}}=\exp \left(-k t^{n}\right)
$$

For study the drying kinetics of soybeans, Overhults et al. [56] modified the Page model and obtained the following equation (this model is known as Modified Page-I Model)

$$
M R=\frac{X-X_{e}}{X_{o}-X_{e}}=\exp (-k t)^{n}
$$

In addition, White et al. (1978) make a little change in (3) to describe the drying kinetics of soybeans (this model is known as Modified Page-II Model)

$$
M R=\frac{X-X_{e}}{X_{o}-X_{e}}=\exp \left((-k t)^{n}\right)
$$

Further, for the drying of sweet potato, Diamante and Munro [57] modified the Page model and proposed the following equation (this model is known as Modified Page Equation (2) Model)

$$
M R=\frac{X-X_{e}}{X_{o}-X_{e}}=\exp \left(-k\left(t / l^{2}\right)^{n}\right)
$$

where $l$ is an empirical constant (dimensionless). 
The drying process of apple and potato is considered as the external resistance to moisture transfer between air and product, therefore, the drying behavior of apple and potato can be characterized by semi-theoretical thin-layer drying models. The above discussed models have been tested for experimental data for apple and potato opted from literature. These models are inadequate to describe the drying behavior of apple and potato in last drying hours. Therefore, in this context we have proposed the following model by adding a linear term in the Lewis model for drying kinetics of apple and potato

$$
M R=\frac{X-X_{e}}{X_{o}-X_{e}}=\exp (-k t)-a k t
$$

where $k$ is the drying constant $\left(\mathrm{m}^{-1}\right)$ and $a$ is the adjusting model constant (dimensionless) introduced for obtaining the best fit of the model to experimental data. The drying constant $k$ depends on drying conditions, temperature, air velocity, humidity and drying methods. The moisture ratio $(M R)$ can be calculated by (7) instead of $\frac{X-X_{e}}{X_{o}-X_{e}}$ due to the small value of $X_{e}$, as compare to $X$, and $X_{o}[58]$.

$$
M R=\frac{X}{X_{o}}
$$

Therefore, (6) reduced to

$$
M R=\frac{X}{X_{o}}=\exp (-k t)-a k t
$$

The theoretical models are derived from Fick's second law of diffusion [21] while semi-theoretical models are generally derived from Fick's second law by its modifications and from Newton's law of cooling [16]. We are more concern for semi-theoretical thin-layer drying model due to better prediction of results as compare to other models [4].

These models are just modification of one model or the other, taking the basis from Newton (Lewis) or Page model as could be seen in the literature [29]. It is to overcome the shortcomings of one another. The models are found to successfully describe the drying behavior (kinetics) of different types of fruits and vegetables. Each of the equations has its own dimensionless (model) constants ( $a, b$, $c, d, l, \propto)$ and drying constants $\left(k, g, h, K_{1}, K_{2}, K_{0}\right)$.

Table 1 below shows the mathematical models applied to thin layer drying curves of various agricultural products.

\section{Classification of Model}

Drying processes are usually modeled using two main models, the distributed element model and the lumped element model [16]. These can be described individually as follows:

\subsection{Distributed Element Model}

This model or system is based on the interaction between time and one or more 
Table 1. Mathematical models applied to thin layer drying curves of various agricultural products.

\begin{tabular}{|c|c|c|c|}
\hline $\mathrm{S} / \mathrm{N}$ & Model Name & Model Equation & Reference \\
\hline 1. & Newton/Lewis & $M R=\exp (-k t)$ & [59] \\
\hline 2. & Page & $M R=\exp \left(-k t^{n}\right)$ & [55] \\
\hline 3. & Modified Page & $M R=\exp \left[(-k t)^{n}\right]$ & {$[60]$} \\
\hline 4. & Modified Page II & $M R=\exp \left(-k\left(\frac{t}{L^{2}}\right)^{n}\right)$ & {$[61][62]$} \\
\hline 5 & Modified Page III & $M R=k \exp \left(-\frac{t}{d^{2}}\right)^{n}$ & [63] \\
\hline 6. & Henderson and Pabis & $M R=a \exp (-k t)$ & {$[64]$} \\
\hline 7. & Logarithmic & $M R=a \exp (-k t)+c$ & [65] \\
\hline 8. & Two Term & $M R=a \exp \left(-k_{0} t\right)+b \exp \left(-k_{1} t\right)$ & [66] \\
\hline 9. & Two Term Exponential & $M R=a \exp (-k t)+(1-a) \exp (k a t)$ & {$[60]$} \\
\hline 10. & Wang and Singh & $\begin{array}{c}M R=M_{o}+a t+b t^{2} \\
M R=1+a t+b t^{2}\end{array}$ & [67] [68] \\
\hline 11. & Singh et al. & $M R=\exp (-k t)-a k t$ & {$[4]$} \\
\hline 12. & $\begin{array}{l}\text { Approximation of Diffusion } \\
\text { (or Diffusion Approach) }\end{array}$ & $M R=a \exp (-k t)+(1-a) \exp (-k b t)$ & [65] \\
\hline 13. & Verma et al. & $M R=a \exp (-k t)+(1-a) \exp (-g b t)$ & [69] \\
\hline 14. & Modified Henderson and Pabis & $M R=a \exp (-k t)+b \exp (-g t)+c \exp (-h t)$ & [50] \\
\hline 15. & Aghabashlo Model & $M R=\exp -\left(\frac{k_{1} t}{1+k_{0} t}\right)$ & [70] \\
\hline 16. & Ademiluyi Modified & $M R=a \exp -(k t)^{n}$ & [71] \\
\hline 17. & Weibull & $M R=\exp \left(-\left(\frac{t}{a}\right)^{b}\right)$ & {$[72]$} \\
\hline 18. & Midilli et al. & $M R=a \exp \left(-k t^{n}\right)+b t$ & {$[61]$} \\
\hline 19. & Peleg Model & $M-M_{o}=-\frac{1}{k_{1}+t k_{2}}, \frac{\mathrm{d} m}{\mathrm{~d} t}=R=-\frac{k_{1}}{k_{1}+t k_{2}}$ & {$[32]$} \\
\hline 20. & Silva et al. & $M R=\exp \left(-a t-b t^{\frac{1}{2}}\right)$ & [73] \\
\hline 21 & Thompson & $t=a \operatorname{In}(M R)+b[\operatorname{In}(M R)]^{2}$ & [74] \\
\hline 22. & Geometric & $M R=a t^{-n}$ & {$[75]$} \\
\hline 23. & $\begin{array}{l}\text { Combined Two } \\
\text { Term and Page }\end{array}$ & $M R=a \exp \left(-k t^{n}\right)+b \exp \left(-h t^{n}\right)$ & {$[76]$} \\
\hline
\end{tabular}




\begin{tabular}{|c|c|c|c|}
\hline \multicolumn{4}{|c|}{ Continued } \\
\hline 24. & Balbay and Sahin & $M R=(1-a) \exp \left(-k t^{n}\right)+b$ & [77] \\
\hline 25. & Hasibuan and Daud & $M R=1-a t^{n} \exp \left(-k t^{n}\right)$ & [78] \\
\hline $26 \backslash$. & Vega-Lemus & $M R=(a+k t)^{2}$ & [79] \\
\hline 27. & $\begin{array}{c}\text { Simplified } \\
\text { Fick's Diffusion }\end{array}$ & $M R=a \exp (-k t)+c$ & [80] \\
\hline 28. & Hii et al. & $M R=a \exp \left(-k_{1} t^{n}\right)+b \exp \left(-k_{2} t^{n}\right)$ & [81] \\
\hline 29. & Diamante et al. & $\operatorname{In}(-\operatorname{InMR})=a+b(\operatorname{Int})+c(\operatorname{Int})^{2}$ & [82] \\
\hline 30. & Demir et al. & $M R=a \exp (-k t)^{n}+b$ & [83] \\
\hline 31. & Parabolic Model & $M R=a+b t+c t^{2}$ & [84] \\
\hline 32. & Logistics & $M R=\frac{b}{1+a \exp (k t)}$ & [85] \\
\hline 33. & Binomial & $M R=a \exp \left(-k_{o} t\right)+b \exp \left(k_{1} t\right)$ & [86] \\
\hline
\end{tabular}

spatial variables for all of its dependent variables. The distributed element model considers the simultaneous mass and heat transfer for the drying processes. It is important to note that the pressure effect is negligible compared to the temperature and moisture effect as reported by Brooker et al. [87].

\subsection{Lumped Element Model}

This model or system considers the effect of time alone on the dependent variables. The lumped element model does not consider the change in temperature of a product and assumes a uniform distribution of drying air temperature within the product. The model includes assumptions from the Luikov equations, that is, the pressure variable is negligible and the temperature is constant [29] [88]. Lumped parameter model can be used as temperature is uniform in thin layer drying [19].

\section{Factors That Affects Drying Kinetics}

Drying of food products like fruits and vegetables are greatly affected by the following factors: drying time, drying temperature, relative air humidity, air flow rate (or velocity), surface area, size (material thickness), volume and local or partial pressure [89].

Amongst these conditions, the most influential in terms of drying fruits and vegetables are material thickness (size) and drying temperature [90] [91] [92]. Thus, Cerquera et al., [93] included air speed, the final moisture content, contraction or shrinkage of the product and the features that are related to the preservation and quality of the food as most influential parameters. During the 
drying process the air velocity and relative humidity were found to be the least significant factors that affect the drying kinetics of fruits and vegetables, while temperature and thickness were reported to be the factors that most affect thin-layer drying kinetics of fruits and vegetables [94]. But Gacula and Singh [95] showed that the temperature has more influence on the drying constant than the thickness. However, the interactions between the temperature and thickness did not significantly affect the value of the drying constant. These findings were similar to those of Wang [96], who worked with potatoes.

\section{Goodness of Fit Statistics}

Thin-layer drying models are evaluated and can be compared using statistical measures. The quality of the fitted models are evaluated with the following statistical measures: Correlation coefficient ( $\mathrm{r}$ or R), coefficient of determination $\left(\mathrm{r}^{2}\right.$ or $\left.\mathrm{R}^{2}\right)$, Reduced chi square $\left(\chi^{2}\right)$, mean bias error $(\mathrm{MBE})$, root mean square error (RMSE), Sum square error (SSE), mean relative error root square (RRMS), modelling efficiency (EF), mean percent error (MPE), Mean square error (MSE). The model with the highest value for $\mathrm{R}$ or $\mathrm{R}^{2}$ will be selected to describe the drying curves when Correlation coefficient or coefficient of determination is used as the statistical measures and the reverse is the case for other statistical measures. Hence, goodness of fit is said to have occurred in a model if $\mathrm{R}^{2}$ value is high and other criteria such as $\chi^{2}$, RMSE, MBE, MPE, SSE, RRMS, EF, MSE values are low [27] [97] [98] [99] [100]. Nonlinear least square method based on the Levenberg-Marquardt method can also be used to fit the experimental data to select equations. The values of coefficient of determination $R^{2}$ can be used to test the linear relationship between experimental and model calculated values [101], and is one of the primary criteria for the selection of best model.

However, the selection of the most appropriate model for describing the drying behaviour of fruits and vegetables does not depend on the number of constants. Rather, it depends on various statistical indicators. The statistical indicators that have often been used to successfully select the most appropriate drying models as reported in literature [102] [103] [104] [105].

Where $N=n$ is the total number of observations, $M R_{\text {exp }, i}$ and $M R_{p r e, i}$ are the experimental and predicted moisture ratio at any observation $i$. High $R^{2}$ value which closer to 1 represents the best fit of the model [106] as can be seen in Table 2.

Table 2 showing various statistical measures (or indicators) which could be used for evaluating the goodness of fit.

\section{Optimization}

Optimization is the action of making the best or most effective use of a situation or resource(s), thus with regards to some criteria. Hence, it is a process of finding the conditions that give the maximum or minimum of a function. It is an act of obtaining the best result under given circumstances [110]. Using optimization 
Table 2. Various statistical measures.

\begin{tabular}{|c|c|c|c|}
\hline $\mathrm{S} / \mathrm{N}$ & $\begin{array}{l}\text { Statistical } \\
\text { Measures }\end{array}$ & FORMULA & References \\
\hline 1. & $\begin{array}{l}\text { Root Mean } \\
\text { Squared } \\
\text { Error }\end{array}$ & $R M S E=\left[\sum_{i=1}^{N} \frac{1}{N}\left(M R_{e x p, i}-M R_{p r e, i}\right)^{2}\right]^{\frac{1}{2}}$ & [19] \\
\hline 2. & $\begin{array}{c}\text { Mean } \\
\text { Bias Error }\end{array}$ & $M B E=\frac{1}{N} \sum_{i=1}^{N}\left(M R_{p r e, i}-M R_{e x p, i}\right)$ & [107] \\
\hline 3. & $\begin{array}{l}\text { Chi Squared } \\
\text { or Reduced } \\
\text { Chi Squared }\end{array}$ & $x^{2}=\sum_{i=1}^{n} \frac{\left(M R_{e x p, i}-M R_{p r e, i}\right)^{2}}{N-n}$ & [19] \\
\hline 4. & $\begin{array}{l}\text { Mean Relative } \\
\text { Deviation } \\
\text { Modulus }\end{array}$ & $P(\%)=\frac{100}{N} \sum_{i=1}^{N}\left|\frac{M R_{Q i}-M R_{e i}}{M R_{e i}}\right|$ & [108] \\
\hline 5. & $\begin{array}{l}\text { Coefficient of } \\
\text { Determination }\end{array}$ & $R^{2}=1-\frac{\sum_{i=1}^{n}\left(M R_{e x p, i i}-M R_{p r e, i}\right)^{2}}{\sum_{i=1}^{n}\left(M R_{e x p, i}-M R_{p r e, i}\right)^{2}}$ & [29] \\
\hline 6. & $\begin{array}{l}\text { Sum } \\
\text { Square Error }\end{array}$ & $S S E=\frac{1}{N} \sum_{i=1}^{N}\left(M R_{e x p, i}-M R_{p r e, i}\right)^{2}$ & [109] \\
\hline 7. & $\begin{array}{l}\text { Modelling } \\
\text { Efficiency }\end{array}$ & $E F=\frac{\sum_{i=1}^{N}\left(M R_{i, \text { exp }}-M R_{i, e x p_{\text {men }}}\right)^{2}-\sum_{i=1}^{N}\left(M R_{i, \text { pre }}-M R_{i, \text { exp }}\right)^{2}}{\sum_{i=1}^{N}\left(M R_{i, e x p}-M R_{i, e x p_{\text {men }}}\right)^{2}}$ & [90] \\
\hline 8. & $\begin{array}{l}\text { Correlation } \\
\text { coefficient }\end{array}$ & $r=\frac{N \sum_{i=1} M R_{p r e, i} M R_{e x p, i}-\sum_{i=1} M R_{p r e, i} \sum_{i=1} M R_{e x p, i}}{\sqrt{\left(N \sum_{i=1}^{N} M R_{p r e, i}^{2}-\left(\sum_{i=1}^{N} M R_{p r e, i}\right)^{2}\right)\left(N \sum_{i=1}^{N} M R_{e x p, i}^{2}-\left(\sum_{i=1}^{N} M R_{e x p, i}\right.\right.}}$ & [16] \\
\hline 9. & $\begin{array}{l}\text { Mean } \\
\text { Relative } \\
\text { Deviation }\end{array}$ & $E(\%)=\frac{100}{N} \sum_{i=1}^{N}\left|\frac{\text { Experimental value }- \text { Predicted value }}{\text { Experimental value }}\right|$ & [43] \\
\hline 10. & $\begin{array}{l}\text { Residual } \\
\text { Sum } \\
\text { of Squares }\end{array}$ & $R S S=\sum_{i=1}^{N}\left(M R_{\text {exp }, i}-M R_{\text {pred }, i}\right)^{2}$ & [85] \\
\hline
\end{tabular}

could help in predicting the best models for the processes of drying agricultural products in thin layers. Nowadays, predictive and very accurate tools such as Artificial Neural Networks (ANN) and Genetic Algorithm (GA) enjoy a special status in predicting and optimizing drying processes of various products [108].

Genetic algorithm is a complicated optimization technique that studies a set of various defined characteristics to reach an optimal value through replication of evolutionary biological processes based on mutation and integration similar to what happens in genetics. This method has been used successfully in investigating various problems [111]. In general, many parameters including population size, number of generations, number of data items, etc. influence the optimization method. The optimal values of these parameters can be obtained through the trial and error method [108]. 
Recently, interest in using Artificial Neural networks (ANN) as a modeling tool in food technology is increasing because they have found extensive utilization in solving many complex real world problems. Artificial neural networks are control systems necessary to solve problems in which the analytical methods are difficult to apply and their results have to be in a specific interval, e.g., in real time. The main objective of ANN is the development of mathematical algorithms that will enable ANNs to learn by mimicking information processing and knowledge acquisition in the human brain [112].

ANN models contain layers of simple computing nodes that operate as nonlinear summing devices. Number of level or layers: the distribution of neurons in the neural network is done forming levels or layers of a determined number of nodes each one. There are input, output and hidden layers [113].

The direction of the information flow is through the layers. The connectivity between the nodes of a neural network is related with the way in which the exits of neurons are directed to become into entrances other neurons. The output signal of a node can be one of the entrances another element of process, or even be an entrance to it. When any output of the neurons is input of neurons of the same level or preceding levels, the network is described as feed-forward. On the contrary, if there is at least one connected exit as entrance of neurons of previous levels or of the same level, including themselves, the network is denominated of feedback. The feedback networks that have at least a closed loop of back propagation are called recurrent [114].

Though, both Response Surface Methodology (RSM) and ANN models provided good quality predictions, yet the ANN shows a clear superiority over RSM for both data fitting and estimation capabilities. On the other hand, ANN has the disadvantage of requiring large amounts of training data in comparison with RSM. This problem is solved by using statistical experimental design, to reduce the number of experiments [115].

The most important stages in a biological process are modeling and optimization to improve a system and increase the efficiency of the process without increasing the cost. The classical optimization method (single variable optimization) is not only time-consuming and tedious but also does not depict the complete effects of the parameters in the process and ignores the combined interactions between physicochemical parameters. This method can also lead to misinterpretation of results. In contrast, response surface methodology (RSM) is an empirical modeling system for developing, improving, and optimizing of complex processes [115].

Although RSM has so many advantages, and has successfully been applied to study and optimize the enzymatic processes and enzyme production from microorganisms, it is hard to say that it is applicable to all optimization and modelling studies. The past decade has seen a host of data analysis tools based on biological phenomena develop into well-established modelling techniques, such as artificial intelligence and evolutionary computing [115]. 
Artificial neural networks (ANNs) are now the most popular artificial learning tool in biotechnology, with a wide applications range included optimization of bioprocesses and enzyme production from microorganisms. Indeed an ANN is a massively interconnected network structure consisting of many simple processing elements capable of performing parallel computation for data processing. The fundamental processing element of ANNs (the artificial neuron) simulates the basic functions of biological neurons [115].

RSM is a frequently used method for empirical modeling and prediction in the processing of biological media. The ANN has recently grown to be one of the most efficient methods for empirical modeling and prediction, especially for non-linear systems [116].

The role model for ANN is the human mind. ANN is a collection of methodologies that intend to utilize the endurance for ambiguity and uncertainty to achieve complete information and provide low cost solutions. ANN is playing an increasingly significant role in many application areas of science, engineering and technology [116] [117].

Neural networks have the potential for solving problems in which some inputs and corresponding output values are known, but the relationship between the inputs and outputs is not well understood or is difficult to translate into a mathematical function. These conditions are commonly found in tasks involving grading, sorting and identifying agricultural products [116].

ANNs are useful tools for food safety and quality analyses, which include modeling of microbial growth, and from this predicting food safety; interpreting spectroscopic data, predicting physical, chemical, functional and sensory properties of various agricultural products during processing, storage and distribution. ANNs hold a great deal of promise for modeling complex tasks in process control and simulation and in applications of machine perception including machine vision and electronic nose for food safety and quality control [116].

The application of ANN for predicting the shelf life of food products in food industry is quite a new and effective approach. ANN procedure is sensitive, reliable, fast, simple and low-cost method for monitoring the authenticity of the products, which provide consumers with a safer food supply [118].

ANN is quite a new and easy computational modeling approach used for prediction, which has become popular and accepted by food industry, researchers, scientists and students [116].

\section{Conclusion}

In conclusion, the most commonly used and newly developed thin layer drying models have been discussed. The development of models and the mechanism of the drying process were explained. Various statistical approaches to determine the best model(s) for the drying processes were explained. But the most widely applied categories of thin-layer models are the semi theoretical and empirical models. Using optimization could help in predicting the best models for the 
processes of drying agricultural products in thin layers. Models have been found to be helpful for food industries to analyze drying kinetics of agricultural products so that the quality of these products can be maintained and assist in reducing losses incurred during bumper harvesting and processing. ANN one of the numerous modeling tools in food technology is quite a new and easy computational modeling approach used for prediction, which has become popular and accepted by the food industry, researchers, scientists and students and have found extensive utilization in solving many complex real world problems.

\section{References}

[1] Ertekin, C. and Yaldiz, O. (2004) Drying of Eggplant and Selection of a Suitable Thin Layer Drying Model. Journal of Food Engineering, 63, 349-359. https://doi.org/10.1016/j.jfoodeng.2003.08.007

[2] Akpinar, E.K. and Bicer, Y. (2004) Modelling of the Drying of Eggplants in Thin-Layers. International Journal of Food Science and Technology, 40, 273-281.

[3] Kabiru, A.A., Joshua, A.A. and Raji, A.O. (2013) Effect of Slice Thickness and Temperature on the Drying Kinetics of Mango (Mangifera Indica). IJRRAS, 15, 41-50.

[4] Singh, F., Katiyar, V.K. and Singh, B.P. (2014) Mathematical Modeling to Study Drying Characteristic of Apple and Potato. International Conference on Chemical, Environment and Biological Sciences, Kuala Lumpur, 17-18 September 2014, 172-175.

[5] Inyang, U., Oboh, I. and Etuk, B. (2017) Drying and the Different Techniques. International Journal of Food Nutrition and Safety, 8, 1-25.

[6] Boekel, M.A.J.S.V. and Tijskens, L.M.M. (2001) Kinetics Modelling. Chapter Three, Wageningen University, Wageningen.

[7] Gupta, S.V. and Patil, N. (2014) Convective Drying of Osmo-Dehydrated Sapota Slice. International Journal of Agricultural and Food Science, 5, 219-226.

[8] Vagenas, G.K. and Marinos-kouris, D. (1991) The Design and Optimization of an Industrial Dryer for Sultana Raisins. Drying Technology, 9, 439-461. https://doi.org/10.1080/07373939108916675

[9] Gekas, V. and Lamberg, I. (1991) Determination of Diffusion Coefficients in Volume Changing Systems-Application in the Case of Potato Drying. Journal of Food Engineering, 13, 317-326. https://doi.org/10.1016/0260-8774(91)90021-J

[10] Karathanos, V.T. and Belessiotis, V.G. (1999) Application of a Thin Layer Equation to Drying Data of Fresh and Semi-Dried Fruits. Journal of Agricultural Engineering, 74, 355-361. https://doi.org/10.1006/jaer.1999.0473

[11] Yun, T.M., Puspasari, I., Tasirin, S.M., Talib, M.Z.M., Daud, W.R.W. and Yaakob, Z. (2013) Drying of Oil Palm Frond Particles in a Fluidized Bed Dryer with Inert Medium. Chemical Industry and Chemical Engineering Quarterly, 19, 593-603. https://doi.org/10.2298/CICEQ120327094Y

[12] Kannan, C.S. and Subramanian, N.B. (2008) Drying Kinetics of Saw Dust in Tray Dryer. Journal of sustainable development, 1, 123-127.

[13] Methakhup, S., Chiewchan, N. and Devahastin, S. (2005) Effects of Drying Methods and Conditions on Drying Kinetics and Quality of Indian Gooseberry Flake. Swiss Society of Food Science and Technology, 38, 579-587.

https://doi.org/10.1016/j.lwt.2004.08.012 
[14] Nimmol, C., Devahastin, S., Swasdisevi, T. and Soponronnarit, S. (2007) Drying of Banana Slices using Combined Low Pressure Superheated Steam and Far-Infrared Radiation. Journal of Food Engineering, 81, 624-633. https://doi.org/10.1016/j.jfoodeng.2006.12.022

[15] Prabhanjan, D.G., Ramaswamy, H.S. and Raghavan, G.S.V. (1995) Microwave-Assisted Convective Air Drying of Thin Layer Carrots. Journal of Food Engineering, 25, 283-293. https://doi.org/10.1016/0260-8774(94)00031-4

[16] Erbay, Z. and Icier, F. (2010) A Review of Thin Layer Drying of Foods: Theory, Modeling, and Experimental Results. Critical Reviews in Food Science and Nutrition, 50, 441-464. https://doi.org/10.1080/10408390802437063

[17] Srikiatden, J. and Roberts, J.S. (2007) Moisture Transfer in Solid Food Materials: A Review of Mechanism, Models and Measurements, International Journal of Food Properties, 10, 739-777. https://doi.org/10.1080/10942910601161672

[18] Naderinezhad, S., Etesami, N., Najafabady, A.P. and Falavarjani, M.G. (2016) Mathematical Modeling of Drying of Potato Slices in a Forced Convective Dryer Based on Important Parameters., Food Science and Nutrition, 4, 110-118.

https://doi.org/10.1002/fsn3.258

[19] Pandey, S.K., Diwan, S. and Soni, R. (2015) Review of Mathematical Modeling of Thin Layer Drying Process. International Journal of current Engineering and Scientific Research, 3, 96-107.

[20] Sahari, Y. and Driscoli, R.H. (2013) Thin Layer Drying of Agricultural Products: A Review. 3rd Malayian Postgraduate Conference, Sydney, 4-5 July 2013, 8-21.

[21] Panchariya, P.C., Popovic, D. and Sharma, A.L. (2002) Thin-Layer Modeling of Black Tea Drying Process. Journal of Food Engineering Davis, 52, 349-357. https://doi.org/10.1016/S0260-8774(01)00126-1

[22] Saeed, I.E, Sopian, K. and Abidin, Z.Z. (2008) Drying Characteristics of Roselle (1): Mathematical Modeling and Drying Experiments. Agricultural Engineering International: CIGR Journal, 10, 1-25.

[23] Akpinar, E.K., Bicer, Y. and Yildiz, C. (2003) Thin-Layer Drying of Red Pepper. Journal of Food Engineering, 59, 99-104. https://doi.org/10.1016/S0260-8774(02)00425-9

[24] Doymaz, I. (2007) Air Drying Characteristics of Tomatoes. Journal of Food Engineering, 78, 1291-1297. https://doi.org/10.1016/j.jfoodeng.2005.12.047

[25] Shanmugama, V. and Natarajan, E. (2006) Experimental Investigation of Forced Convection and Desiccant Integrated Solar Dryer. Renewable Energy, 31, 1239-1251. https://doi.org/10.1016/j.renene.2005.05.019

[26] Prachayawarakorn, S., Tia, W., Plyto, N. and Soponronnarit, S. (2008) Drying Kinetics and Quality Attributes of Low-Fat Banana Slices Dried at High Temperature. Journal of Food Engineering, 85, 509-517. https://doi.org/10.1016/j.jfoodeng.2007.08.011

[27] Saeed, I.E., Sopian, K. and Zainol Abidin, Z. (2006) Drying Kinetics of Roselle (Hibiscus sabdariffa L.): Dried in Constant Temperature and Humidity Chamber. In: Muchtar, Ed., Proceedings of SPS, Permata, Bangi, S.D.E., Malaysia, 143-148.

[28] Togrul, Ý.T. and Pehlivan, D. (2003) Modelling of Drying Kinetics of Single Apricot. Journal of Food Engineering, 58, 23-32. https://doi.org/10.1016/S0260-8774(02)00329-1

[29] Onwude, D.I., Hanshim, N., Janius, R.B., Nawi, N.M. and Abdan, K. (2016a) Modeling the Thin Layer Drying of Fruits and Vegetables: A Review. Comprehensive 
Reviews in Food Science and Food Safety, 15, 299-618. https://doi.org/10.1111/1541-4337.12196

[30] Carrin, M.E. and Crapiste, G.H. (2008) Convective Drying of Foods. In: Ratti, C., Ed., Advances in Food Dehydration, CRC Press, Boca Raton, 123-152. https://doi.org/10.1201/9781420052534.ch5

[31] Araya-Farias, M. and Ratti, C. (2009) Dehydration of Foods: General Concepts. In: Ratti, C., Ed., Advances in Food Dehydration, CRC Press, Boca Raton, 1-36.

[32] Khazaei, J. and Daneshmandi, S. (2007) Modeling of Thin-Layer Drying Kinetics of Sesame Seeds: Mathematical and Neural Networking Modeling. International Agrophysics, 21, 335-348.

[33] Akpinar, E.K. (2006) Determination of Suitable Thin-Layer Drying Curve Model for Some Vegetables and Fruits. Journal of Food Engineering, 73, 75-84. https://doi.org/10.1016/j.jfoodeng.2005.01.007

[34] Doymaz, I. (2007) The Kinetics of Forced Convective Air-Drying of Pumpkin Slices. Journal of Food Engineering, 79, 243-248. https://doi.org/10.1016/j.jfoodeng.2006.01.049

[35] Raquel, P.F., Susana, P. and Maria, J.B. (2011) Study of the Convective Drying of Pumpkin (Cucurbita maxima). Food Bioprod Process, 89, 422-428. https://doi.org/10.1016/j.fbp.2010.09.001

[36] Ikrang, E.G. (2014) Development of a Model for Thin Layer Solar Drying of Salted Fish Fillets. PhD Thesis, Department of Agricultural and Bioresources Engineering, University of Nigeria, Nsukka.

[37] Henderson, S.M., Perry, R.L. and Young, J.H. (1997) Principles of Process Engineering, ASAE.

[38] Ronoh, E.K., Kanali, C.L., Mailutha, J.T. and Shitanda, D. (2010) Thin Layer Drying Kinetics of Amaranth (Amaranthus cruentus) Grains in a Natural Convection Solar Tent Dryer. African Journal of Food, Agriculture, Nutrition and Development, 10, 2218-2233. https://doi.org/10.4314/ajfand.v10i3.54080

[39] Omid, M., Yadollahinia, A.R. and Rafiee, S. (2006) A Thin Layer Drying Model for Paddy Dryer. Proceedings of the International Conference on Innovations in Food and Bioprocess Technologies, Pathumthani, 12-14 December 2006, 202-211.

[40] Henderson, S.M. (1974) Progress in Developing the Thin Layer Drying Equation. Transactions of the American Society of Agricultural Engineers, 17, 1167-1172. https://doi.org/10.13031/2013.37052

[41] Whitaker, T., Barre, H.J. and Hamdy, M.Y. (1969) Theoretical and Experimental Studies of Diffusion in Spherical Bodies with a Variable Diffusion Coefficients. Transactions of ASAE, 11, 668-672. https://doi.org/10.13031/2013.38924

[42] Bruce, D.M. (1985) Exposed Layer Barley during, Three Models Fitted to New Data up to $150^{\circ} \mathrm{C}$. Journal of Agricultural Engineering Research, 32, 337-347. https://doi.org/10.1016/0021-8634(85)90098-8

[43] Fernando, J.A.K.M. and Amarasinghe, A.D.U.S. (2016) Drying Kinetics and Mathematical Modeling of Hot Air Drying of Coconut Coir Pith, Fernando and Amarasinghe. Springer Plus, 5, 807. https://doi.org/10.1186/s40064-016-2387-y

[44] Coradi, P.C., Melo, E.D.C. and Rocha, R.P.D. (2014) Mathematical Modeling of the Drying Kinetics of the Leaves of Lemon Grass (Cymbopogon citratus Stapf) and Its Effects on Quality. IDESIA (Chile), 32, 43-56. https://doi.org/10.4067/S0718-34292014000400006

[45] Irudayaraj, J., Haghighi, K. and Stroshine, R.H. (1992) Finite Element Analysis of 
Drying with Application to Cereal Grains. Journal of Agricultural Engineering Research, 53, 209-229. https://doi.org/10.1016/0021-8634(92)80084-6

[46] Kemp, I.C. (2011) Drying Models, Myths and Misconceptions. Chemical Engineering \& Technology, 34, 1057-1066. https://doi.org/10.1002/ceat.201100061

[47] Brooker, D.B., Baker-Arkema, F.W. and Hall, C.W. (1992) Drying and Storage of Grains and Oilseeds. AVI Book, New York, 450 p.

[48] Parry, J.L. (1985) Mathematical Modeling and Computer Simulation of Heat and Mass Transfer in Agricultural Grain Drying. Journal of Agricultural Engineering Research, 32, 1-29. https://doi.org/10.1016/0021-8634(85)90116-7

[49] Marinos-Kouris, D. and Maroulis, Z.B. (1995) Transport Properties in the Drying of Solids. In: Mujumdar, A.S., Eds., Handbook of Industrial Drying, 2nd Edition, Marcel Dekker Inc., New York, 113-160.

[50] Karathanos, V.T. (1999) Determination of Water Content of Dried Fruits by Drying Kinetics. Journal of Food Engineering, 39, 337-344. https://doi.org/10.1016/S0260-8774(98)00132-0

[51] Henderson, S.M. and Pabis, S. (1961) Grain Drying Theory I. Temperature Effects on Drying Coefficient. Journal of Agricultural Engineering Research, 6, 169-174.

[52] Misha, S., Mat, S. and Ruslan, M.H. (2013) The Effect of Drying Air Temperature and Humidity on the Drying Kinetics of Kenaf Core. Applied Mechanics and Materials, 315, 710-714. https://doi.org/10.4028/www.scientific.net/AMM.315.710

[53] Maisnam, D., Rasane, P., Dey, A., kaur, S. and Sarma, C. (2017) Recent Advances in Conventional Drying of Foods. Journal of Food Technology and Preservation, 1, 25-34.

[54] Lewis, W.K. (1921) The Rate of Drying of Solid Materials. Journal of Industrial \& Engineering Chemistry, 13, 427-432. https://doi.org/10.1021/ie50137a021

[55] Page, G.E. (1949) Factors Influencing the Maximum Rate of Air Drying Shelled Corn in Thin-Layers. M.S. Thesis, Purdue University, West Lafayette.

[56] Overhult, D.G., White, G.M., Hamilton, H.E. and Ross, I.J. (1973) Drying Soybeans with Heated Air. Transactions of the ASAE, 16, 112-113. https://doi.org/10.13031/2013.37459

[57] Diamante, L.M. and Munro, P.A. (1993) Mathematical Modelling of the Thin Layer Solar Drying of Sweet Potato Slices. Solar Energy, 51, 271-276. https://doi.org/10.1016/0038-092X(93)90122-5

[58] Sacilik, K. and. Elicin, A.K. (2006) The Thin Layer Drying Characteristics of Organic Apple Slices. Journal of Food Engineering, 73, 281-289. https://doi.org/10.1016/j.jfoodeng.2005.03.024

[59] Westerman, P.W., White, G.M. and Ross, I.J. (1973) Relative Humidity Effect on the High Temperature Drying of Shelled Corn. Transactions of the ASAE, 16, 1136-1139. https://doi.org/10.13031/2013.37715

[60] Yaldiz, O., Ertekin, C. and Uzun, H.B. (2001) Mathematical Modelling of Thin Layer Solar Drying of Sultana Grapes. Energy, 26, 457-465. https://doi.org/10.1016/S0360-5442(01)00018-4

[61] Midilli, A., Kucuk, H. and Yapar, Z.A. (2002) New Model for Single Layer Drying. Drying Technology, 20, 1503-1513. https://doi.org/10.1081/DRT-120005864

[62] Wang, Z., Sun, J., Liao, X., Chen, F., Zhao, G., Wu, J. and Hu, X. (2007) Mathematical Modeling on Hot Air Drying of Thin Layer Apple Pomace. Journal of Food Engineering, 40, 39-46. https://doi.org/10.1016/j.foodres.2006.07.017

[63] Kumar, P.D.G., Hebber, H. and Ramesh, M.N. (2006) Suitability of Thin Layer 
Models for Infrared Hot Air Drying of Onion Slices. LWT-Food Science and Technology, 39, 700-705. https://doi.org/10.1016/j.lwt.2005.03.021

[64] Yagcioglu, A., Degirmencioglu, A. and Cagatay, F. (1999) Drying Characteristics of Laurel Leaves under Different Conditions. Proceedings of the 7 th International Congress on Agricultural Mechanization and Energy, Adana, 26-27 May 1999, 565-569.

[65] Yaldiz, O. and Ertekin, C. (2001) Thin Layer Solar Drying of Some Vegetables. Drying Technology, 19, 583-597. https://doi.org/10.1081/DRT-100103936

[66] Rahman, M.S., Perera, C. and Thebaud, C. (1998) Desorption Isotherm and Heat Pump Drying Kinetics of Peas. Journal of food research International, 30, 485-491.

[67] Ozdemir, M. and Devres, Y.O. (1999) The Thin Layer Drying Characteristics of Hazelnuts during Roasting. Journal of Food Engineering, 42, 225-233. https://doi.org/10.1016/S0260-8774(99)00126-0

[68] Omolola, A.O., Jideani, A.I.O. and Kapila, P.F. (2015) Drying Kinetics of Banana (Musa Spp.). Interciencia, 40, 374-380.

[69] Verma, L.R., Bucklin, R.A., Endan, J.B. and Wratten, F.T. (1985) Effects of Drying Air Parameters on Rice Drying Models. Transactions of the ASAE, 28, 296-301. https://doi.org/10.13031/2013.32245

[70] Aghabashlo, M., Kianmehr, M.H. and Khani, S. (2008) Mathematical Modeling of Carrot Thin Layer Drying using New Model. Energy Conversion and Management, 49, 201-212.

[71] Ademiluyi, T., Oboho, E.O. and Owudogu, M. (2008) Investigation into the Thin Layer Drying Models of Nigerian Popcorn Varieties. Loenardo Electronic Journal of Practices and Technologies, 7, 47-62.

[72] Corzo, O., Bracho, N., Pereira, A. and Vasquez, A. (2008) Weibull Distribution for Modeling Air Drying of Coroba Slices. Journal of Food Science and Technology, 41, 2023-2028. https://doi.org/10.1016/j.lwt.2008.01.002

[73] Da Silva, W.P., Silva, C.M.D.P.S., Farias, V.S.O. and Gomes, J.P. (2012) Diffusion Models to Describe the Drying Process of Peeled Bananas: Optimization and Simulation. Drying Technology, 30, 164-174. https://doi.org/10.1080/07373937.2011.628554

[74] Thompson, T.L., Peart, R.M. and Foster, G.H. (1968) Mathematical Simulation of Corn Drying-A New Model. Transaction of the ASAE, 11, 582-586. https://doi.org/10.13031/2013.39473

[75] Chandra, P.K. and Singh, R.P. (1995) Applied Numerical Methods for Food and Agricultural Engineers. CRC Press, Boca Raton, 163-167.

[76] Hii, C.L., Law, C.L. and Cloke, M. (2008) Modeling of Thin Layer Drying Kinetics of Cocoa Beans during Artificial and Natural Drying. Journal of Engineering Science and Technology, 3, 1-10.

[77] Balbay, A. and Sahin, O. (2012) Microwave Drying Kinetics of a Thin Layer Liquorice Root. Drying Technology, 30, 859-864. https://doi.org/10.1080/07373937.2012.670682

[78] Ertekin, C. and Heybeli, N. (2014) Thin Layer Infrered Drying of Mint Leaves. Journal of Food Processing and Preservation, 38, 1480-1490. https://doi.org/10.1111/jfpp.12107

[79] Barroca, M.J. and Guine, R.P.F. (2012) Study of Drying Kinetics of Quince. Proceedings (Electronic) DA International Conference of Agricultural Engineering, Valenda, 8-12 July 2012. 
[80] Celma, A.R., Rojas, S., Lopez, F., Montero, T. and Miranda, T. (2007) Thin Layer Drying Behavior of Sludge of Olive Oil Extraction. Journal of Food Engineering, 80, 1261-1271. https://doi.org/10.1016/j.jfoodeng.2006.09.020

[81] Kumar, N., Sarkar, B.C. and Sharma, H.K. (2012) Mathematical Modeling of the Thin Layer of Hot Air Drying Carrot Pomace. Journal of Food Science and Technology, 49, 33-41. https://doi.org/10.1007/s13197-011-0266-7

[82] Diamante, L., Durand, M., Savage, G. and Vanhanen, L. (2010) Effect of Temperature on the Drying Characteristics, Colour and Ascorbic Acid Content of Green and Gold Kiwifruits. International Food Research Journal, 45, 441-451.

[83] Demir, V., Gunhan, T. and Yagcioglu, A.K. (2007) Mathematical Modeling of Convection Drying of Green Table Olives. Biosystems Engineering, 98, 47-53. https://doi.org/10.1016/j.biosystemseng.2007.06.011

[84] Sharma, G.P. and Prasad, S. (2004) Effective Moisture Diffusivity of Garlic Cloves Undergoing Microwave Convective Drying. Journal of Food Engineering, 65, 605-617. https://doi.org/10.1016/j.jfoodeng.2004.02.027

[85] Shah, S. and Joshi, M. (2010) Modelling Microwave Drying Kinetics of Sugarcane Bagasse. International Journal of Electronic Engineering, 2, 159-163.

[86] Laohavanich, J. and Wongpichet, W. (2008) Thin Layer Drying Model for Gas-Fired Infrared Drying of Paddy. Songklanakarin Journal of Science and Technology, 30, 343-348.

[87] Brooker, D.B., Bakker-Arkema, F.W. and Hall, C.W. (1974) Drying Cereal Grains. The AVI Publishing Company Inc., Westport.

[88] Luikov, A.V. (1975) Systems of Differential Equations of Heat and Mass Transfer in Capillary-Porous Bodies (Review). International Journal of Heat and Mass Transfer, 18, 1-14. https://doi.org/10.1016/0017-9310(75)90002-2

[89] Chayjan, R.A. (2012) Modeling Some Drying Characteristics of High Moisture Potato Slices in Fixed, Semi Fluidized and Fluidized Bed Conditions. Journal of Agricultural Science and Technology, 14, 1229-1241.

[90] Meisamiasl, E., Rafiee, S., Keyhani, A. and Tabatabaeefar, A. (2010) Determination of Suitable Thin-Layer Drying Curve Model for Apple Slices (Golab). Plant OMICS, 3, 103-108.

[91] Pandey, H., Sharma, H.K., Chauhan, R.C., Sarkar, B.C. and Bera, M.B. (2010) Experiments in Food Process Engineering. CBS Publisher and Distributors PVT, New Delhi, 139-145.

[92] Kumar, C., Karim, A., Joardder, M.U.H. and Miller, G.J. (2012a) Modeling Heat and Mass Transfer Process during Convection Drying of Fruit. The 4th International Conference on Computational Methods, Gold Coast, 25-27 November 2012.

[93] Cerquera, N.E., Pastrana, E. and Castro, J.K. (2017) Determination of the Drying Variables for Dehydration of Banana Pulp Sheets (Musa Paradisiaca L.). ARPN Journal of Engineering and Applied Sciences, 12, 160-167.

[94] Gacula, M.C. and Singh, J. (1984) Statistical Methods in Food and Consumer Research. Applied Science, London, 505.

[95] Onwude, D.I., Hanshim, N., Janius, R.B., Nawi, N.M. and Abdan, K. (2016b) Evaluation of a Suitable Thin Layer Model for Drying of Pumpkin under Forced Air Convection. International food Research Journal, 23, 1173-1181.

[96] Wang, N. (1992) Convective Drying: Modelling and Water Solid Interactions. PhD Thesis, Department of Food Science and Technology, The University of Reading, Reading. 
[97] Doymaz, I. (2004) Convective Air Drying Characteristics of Thin Layer Carrots. Journal of Food Engineering, 61, 359-364. https://doi.org/10.1016/S0260-8774(03)00142-0

[98] Kingsly, A.R.P. and Singh, D.B. (2007) Drying Kinetics of Pomegranate Arils. Journal of Food Engineering, 79, 741-744. https://doi.org/10.1016/j.jfoodeng.2006.02.033

[99] Maydeu-Olivares, A. and Garcia-Forero, C. (2010) Goodness-of-Fit Testing. International Encyclopedia of Education, 7, 190-196. https://doi.org/10.1016/B978-0-08-044894-7.01333-6

[100] Demir, V., Gunhan, T., Yagcioglu, A.K. and Degirmencioglu, A. (2004) Mathematical Modeling and the Determination of Some Quality Parameters of Air Dried Bay Leaves. Biosystems Engineering, 88, 429-437. https://doi.org/10.1016/j.biosystemseng.2004.04.005

[101] Gunhan, T., Demir, V., Hancioglu, E. and Hepbasli, A. (2005) Mathematical Modelling of Drying of Bay Leaves. Energy Conversion and Management, 46, 1667-1679. https://doi.org/10.1016/j.enconman.2004.10.001

[102] Tzempelikos, D.A., Vouros, A.P., Bardakas, A.V., Filios, A.E. and Margaris, D.P. (2014) Case Studies on the Effect of the Air Drying Conditions on the Convective Drying of Quinces. Case Study. Thermal Engineering, 3, 79-85. https://doi.org/10.1016/j.csite.2014.05.001

[103] Darıc1, S. and Sen, S. (2015) Experimental Investigation of Convective Drying Kinetics of Kiwi under Different Conditions. Heat Mass Transfer, 51, 1167-1176. https://doi.org/10.1007/s00231-014-1487-x

[104] Onwude, D.I., Hashim, N., Janius, R., Nawi, N. and Abdan, K. (2015a) Computer Simulation of Convective Hot Air Drying Kinetics of Pumpkin (Cucurbita moschata). The 8 th Asia-Pacific Drying Conference, Kuala Lumpur, 10-12 August 2015, 122-129.

[105] Tzempelikos, D.A., Vouros, A.P., Bardakas, A.V., Filios, A.E. and Margaris, D.P. (2015) Experimental Study on Convective Drying of Quince Slices and Evaluation of Thin-Layer Drying Models. Engineering in Agriculture, Environment and Food, 8, 169-177. https://doi.org/10.1016/j.eaef.2014.12.002

[106] Chen, J., Zhou, Y., Fang, S., Meng, Y., Kang, X., Xu, X. and Zuo, X. (2013) Mathematical Modeling of Hot Air Drying Kinetics of Momordica charantia Slices and Its Color Change. Advance Journal of Food Science and Technology, 5, 1214-1219.

[107] Sridhar, D. and Madhu, G.M. (2015) Drying Kinetics and Mathematical Modeling of Casuarinas Equisetifolia Wood Chips at Various Temperatures. Periodica Polytechnica Chemical Engineering, 59, 288-295. https://doi.org/10.3311/PPch.7855

[108] Shahi, M.M.N., Mohsen Mokhtarian, M. and Entezari, A. (2014) Optimization of Thin Layer Drying Kinetics of Kiwi Fruit Slices using Genetic Algorithm. Advances in Natural and Applied Sciences, 8, 11-19.

[109] Afolabi, T.J., Tunde-Akintunde, T.Y. and Adeyanju, J.A. (2015) Mathematical Modelling of Kinetics of Untreated and Pre-Treated Cocoyam Slices. Journal of food sciences Technology, 52, 2731-2740. https://doi.org/10.1007/s13197-014-1365-Z

[110] Jadhav, A. and Gore, N.G. (2016) Cost Optimization of Roof Top Swimming Pool. International Research Journal of Engineering and Technology, 3, 1320-1322.

[111] Goldberg, D. (1989) Genetic Algorithms in Search, Optimization and Machine Learning. Addison-Wesley Pub. Co., Boston.

[112] Basheer, I.A. and Hajmeer, M. (2000) Artificial Neutral Networks: Fundamentals, 
Computing, Design and Application. Journal of Microbiological Methods, 43, 3-31. https://doi.org/10.1016/S0167-7012(00)00201-3

[113] Akerkar, R. and Sajja, P.S. (2016) Intelligent Techniques for Data Science. Springer International Publishing, Berlin. https://doi.org/10.1007/978-3-319-29206-9

[114] Funes, E., Allouche, Y., Beltrán, G. and Jiménez, A. (2015) A Review: Artificial Neural Networks as Tool for Control Food Industry Process. Journal of Sensor Technology, 5, 28-43. https://doi.org/10.4236/jst.2015.51004

[115] Ebrahimpour, A., Rahman, R.N.Z.R.A., Chng, D.H.E., Basri, M. and Salleh, A.B. (2008) A Modeling Study by Response Surface Methodology and Artificial Neural Network on Culture Parameters Optimization for Thermostable Lipase Production from a Newly Isolated Thermophilic Geobacillus sp. Strain ARM. BMC Biotechnology, 8, 15. https://doi.org/10.1186/1472-6750-8-96

[116] Goyal, S. (2014) Artificial Neural Networks in Fruits: A Comprehensive Review. International Journal of Image, Graphics and Signal Processing, 5, 53-63. https://doi.org/10.5815/ijigsp.2014.05.07

[117] Pannu, A. (2015) Artificial Intelligence and Its Application in Different Areas. International Journal of Engineering and Innovative Technology, 4, 79-84.

[118] Goyal, S. and Goyal, G.K. (2012) Artificial Neural Network for Diary Industry: A Review. Journal of Advanced Computer Science and Technology, 1, 101-115. 